Jurnal Akuntansi dan Investasi, Vol. 18 No. 2, Hlm: 172-182 Juli 2017

Artikel ini tersedia di website: http://journal.umy.ac.id/index.php/ai

DOI: $10.18196 /$ jai.180281

\title{
Determinan Kinerja Pengelolaan Keuangan Desa: Studi pada Kecamatan Gandapura Kabupaten Bireuen Aceh
}

\author{
Finta Munti dan Heru Fahlevi* \\ Program Studi Akuntansi Universitas Syiah Kuala, Jln. Teuku Nyak Arief, Darussalam, Kopelma \\ Darussalam, Syiah Kuala, Kota Banda Aceh, Aceh 23111, Indonesia
}

\begin{tabular}{l}
\hline A R T I C L E I N F O \\
\hline Article history: \\
received 18 Mar 2017 \\
revised 12 Jun 2017 \\
accepted 17 Jun 2017 \\
\\
Keywords: \\
Financial Management; \\
Officers' Capacity; \\
Financial Reporting \\
Compliance; \\
Supervision Quality; \\
Village Fund
\end{tabular}

\begin{abstract}
A B S T R A C T
The objective of this study is to investigate the determinants of Village Financial Management Performance in Gandapura village in the District of Bireuen - Aceh. The tested variables are village officers' capacity, financial reporting compliance, and supervision quality of Badan Permusyawaratan Desa (BPD). The population is all village within Gandapura district, Bireuen, which consists of 40 villages in total. This study involved all the population as the sample. Seletected respondents are Keuchik (or head of villages), village treasurers, Tuha Peut (or village legislative/supervision board), and village facilitators. The data collected through questionaraires and analysed by using multiple linear analysis. This study uncovered an empirical evidence on the effect of village officers' capacity, financial reporting compliance, and supervision quality both collectively and indivdually on the village Financial Management Performance.
\end{abstract}

(C) 2017 JAI. All rights reserved

\section{PENDAHULUAN}

Undang-undang (UU) No. 6 Tahun 2014 tentang Desa dapat dipandang sebagai elemen utama dari usaha yang sedang dilakukan oleh pemerintah Indonesia dalam memperluas desentralisasi sampai ke elemen pemerintahan terkecil. Usaha ini merupakan bentuk kesinambungan proses desentralisasi yang telah dimulai lebih dari lima belas tahun lalu (Antlöv et al., 2016). Lebih dari 74.000 desa di Indonesia kini diposisikan sebagai bagian pemerintahan terkecil dalam ruang lingkup kabupaten di Indonesia, bahkan telah menjadi daerah yang istimewa dan mandiri yang berada dalam ruang lingkup wilayah kabupaten (UU No. 32 tahun 2004).

Selain keleluasaan dalam mengelola pemerintahan, para aparatur desa juga dibekali dengan dana transfer langsung dari pemerintah pusat atau dikenal dengan Alokasi Dana Desa (ADD). Dalam APBN 2016, anggaran ADD dialokasikan sebesar Rp 46,9 triliun. Angka ini hampir dua kali lipat ADD pada APBN 2015 yaitu sebesar Rp 20,7 triliun. Untuk 2017, Pemerintah merencanakan untuk menambah ADD menjadi Rp 89 triliun atau lebih dari Rp 1 miliar untuk setiap desa. Dana yang besar ini diharapkan dapat mempercepat peningkatan kesejahteraan masya- rakat desa melalui pembangunan yang bersifat pemberdayaan dan berkesinambungan.

Namun, permasalahan pengelolaan dana desa yang tidak efisien dan efektif telah menjadi sorotan publik. Kasus penyelewengan dan korupsi dana desa juga telah banyak mencuat di media massa. Lemahnya pengelolaan dana desa ini tampaknya bersifat sistematis yang dikonfirmasi oleh hasil kajian sejumlah kajian evaluasi sejumlah institusi pemerintah dan Lembaga Swadaya Masyarakat (LSM). Misalnya, Badan Pengawasan Keuangan dan Pembangunan (BPKP) menemukan 15.100 Potensi Kelemahan Akuntabilitas Pengelolaan Dana Desa (BPKP, 2015). KPK dan LSM Fitra juga telah merilis hasil kajian mengenai permasalahan dan potensi penyimpangan dana desa (KPK, 2015; Fitra, 2016.

Kinerja pengelolaan keuangan desa akan menentukan tercapai atau tidaknya tujuan dana desa. Kinerja pengelolaan keuangan yang buruk yang ditandai dengan pencatatan dan pelaporan yang tidak konsisten dan sesuai standar dapat membuat proses evaluasi penggunaan dana menjadi sulit dilakukan. Lebih penting lagi adalah tingkat efisiensi dan efektivitas pengelolaan keuangan desa akan ditentukan oleh kemampuan para aparatur desa mengelola dana desa yang mereka miliki. Permendagri Nomor 113 Tahun 2014 
tentang Pengelolaan Keuangan Desa mengisyaratkan pentingnya penerapan asas-asas transparansi, akuntabilitas, partisipatif dalam penyusunan anggaran desa.

Dari sisi literatur, penelitian terkait dengan kinerja pengelolaan keuangan desa masih sangat terbatas dan belum menemukan determinan yang sudah konsisten teruji. Jaitun (2013) menemukan bahwa kerja sama, kedisiplinan, kreativitas, dan tanggung jawab berpengaruh terhadap kinerja pengelolaan keuangan desa. Selanjutnya, Adha (2016) menemukan bahwa kinerja kepala desa Rambah Utama Kecamatan Rambah Samo di Kabupaten Rokan Hulu dipengaruhi secara positif oleh pengawasan BPD (Badan Permusyawaratan Desa).

Dalam konteks besaran dana desa, Aceh berada diurutan ketiga yang menjadi provinsi yang paling banyak menerima dana desa (DJPK, 2015). Kabupaten di Aceh yang mendapatkan porsi paling banyak salah satunya adalah Kabupaten Bireuen Rp 158,871 miliar (DJPK, 2015). Namun demikian, kualitas pengelolaan keuangan desa masih rendah dilihat dari segi kemampuan dan kapasitas aparatur Gampong' yang kurang memahami mengenai tata cara pengelolaan keuangan desa. Fenomena rendahnya kualitas pengelolaan keuangan desa masih banyak ditemui di wilayah Aceh. Provinsi Aceh sebagai penerima dana desa urutan ketiga terbanyak tetapi masih banyak permasalahan dalam pengelolaan keuangan desa. Masih ada Gampong di Aceh yang belum mampu menyusun anggaran pendapatan dan belanja Gampong (APBG) sesuai dengan peraturan undang-undang dan mengelola dana desa dengan baik dan sebagian lain tidak mempublikasikan laporan keuangan (hasil wawancara awal dengan aparat Gampong di Bireuen). Disamping itu, LPJ (Laporan Pertanggung Jawaban) tahun 2015 belum dipertanggungjawabkan kepada masyarakat (Sopan, 2016). Berdasarkan pertimbangan ini, kabupaten Bireuen dijadikan lokasi penelitian disamping kemudahan akses dalam mendapatkan data penelitian.

Penelitian ini merupakan pengembangan dari penelitian sebelumnya mengenai kinerja keuangan dana desa. Penelitian terdahulu mengenai kinerja keungan desa umumnya bersifat eksploratif dan studi kasus seperti Subroto (2009), Lestari et al. (2014), Amirullah et al. (2016), dan Sofyani (2017). Penelitian ini menggunakan pendekatan

\footnotetext{
${ }^{1}$ Berdasarkan Undang Undang Pemerintah Aceh, istilah desa diganti Gampong.
}

kuantitatif untuk menemukan bukti empiris mengenai pengaruh kapasitas aparatur desa, ketaatan pelaporan keuangan dan kualitas pengawasan Badan Pemusyawarahan Desa (BPD) terhadap kinerja keuangan desa. Hasil penelitian ini akan membantu pemerintah daerah khususnya pemerintah desa dalam meningkatkan kinerja keuangan desa. Pada bagian selanjutnya dibahas mengenai konsep pengelolaan dana desa dan hipotesis yang diuji yang diikuti dengan gambaran mengenai desain penelitian, hasil dan pembahasan. Pada bagian akhir dipaparkan mengenai kesimpulan, keterbatasan dan saran untuk penelitian selanjutnya.

\section{TINJAUAN LITERATUR DAN PERUMUSAN HIPOTESIS}

\section{Kinerja Pengelolaan Keuangan Desa}

Dalam UU No. 6 Tahun 2014 mengenai Desa, dijelaskan bahwa desa merupakan kesatuan masyarakat yang berdasarkan hukum dengan batas area dan wewenang untuk mengelola serta melaksanakan urusan di dalam pemerintahan, kepentingan dari masyarakat setempat menurut inisittif masyarakat, hak atas asal usul, atau hak secara tradisional yang telah diakui dan dihormati dalam sistem pemerintahan Negara Kesatuan Republik Indonesia. Dari segi politis undangundang ini memberikan sebuah pelimpahan wewenang dari pemerintah pusat kepada pemerintah desa. Berdasarkan PP No. 43 Tahun 2014 mengenai Peraturan Pelaksanaan Undang-Undang No. 6 Tahun 2014 tentang desa pasal 34, desa memiliki wewenang berdasarkan hak asal-usulnya dalam mengurusi sistem di organisasi masyarakat, pembinaan kelembagaan bagi masyarakat dan lembaga hukum, pengelolaan atas tanah kas desa, dan pengembangan peranan masyarakat desa. Lebih lanjut, masa pengelolaan keuangan desa adalah 1 tahun anggaran (1 Januari s.d. 31 Desember). Dalam konteks ini, kepala desa memegang kekuasaan pengelolaan keuangan desa serta mewakili pemerintah desa dalam kepemilikan kekayaan desa terpisah dengan dibantu oleh PTPKD (Pelaksana Teknis Pengelolaan Keuangan Desa). PTPKD ini berasal dari unsur perangkat desa yang terdiri dari sekretaris desa, kepala seksi, dan bendahara.

Sebagaimana dikemukakan oleh Moeheriono (2012), kinerja adalah deskripsi tentang level prestasi pelaksanaan suatu program, atau kegiatan 
dalam merealisasikan sasaran, tujuan, visi, dan misi organisasi yang tertuang dalam perencanaan jangka panjang organisasi. Selanjutnya Mangkunegara (2007) membagi kinerja dalam dua, yaitu kinerja individu dan kinerja organisasi. Kinerja perlu diukur untuk menilai sejauh mana perbedaan antara rencana yang telah disusun dengan yang sudah direalisasi, jadwal pelaksanaan yang direncanakan dengan realisasinya serta antara hasil yang diperoleh dengan hasil yang diharapkan (Wibowo, 2011). Dari segi keuangan, kinerja merupakan gambaran kondisi keuangan perusahaan pada suatu periode tertentu menyangkut aspek penghimpunan dana maupun penyaluran dana, yang biasanya diukur dengan indikator kecukupan modal, likuiditas, dan profitabilitas (Jumingan, 2006; Yuliyanti, 2014).

Menurut Permendagri No. 113 Tahun 2014 tentang Pengelolaan Keuangan Desa, pengelolaan keuangan desa didefinisikan sebagai semua kegiatan yang meliputi perencanaan, pelaksanaan, pelaporan, dan pertanggungjawaban keuangan desa. Jadi dapat disimpulkan bahwa kinerja pengelolaan keuangan desa adalah hasil kerja atau prestasi aparatur desa dalam melaksanakan seluruh kegiatan meliputi perencanaan, pelaksanaan, pelaporan, dan pertanggung jawaban keuangan desa. Penyelenggaraan keuangan desa yang ditugaskan oleh pemerintah didanai oleh APBN.

Dalam ketentuan umum Permendagri No. 37 Tahun 2007 tentang Pengelolaan Keuangan Daerah juga dijelaskan pemberikan hak otonom kepada desa bertujuan untuk memberikan kesempatan pemerintah desa untuk mengelola keuangan secara sendiri termasuk dalam pengelolaan pendapatan dan sumber-sumber pendapatan, juga pembelanjaan anggaran. Kinerja dapat didefinisikan sebagai kemampuan dalam melaksanakan suatu kegiatan dalam pencapaian tujuan, visi, dan misi sebuah organisasi (Nurzianti dan Anita, 2014)

Disamping itu, Mardiasmo (2009) mengemukakan bahwa indikator kinerja dapat diukur dengan menggunakan indikator (1) efisiensi yaitu perbandingan antara output dan input yang dikaitkan dengan target atau standar kinerja yang telah ditetapkan, (2) efektivitas adalah tingkat perbandingan antara pencapaian hasil program dengan target yang ditetapkan, (3) ekonomis adalah perbandingan antara input dan input value yang dinyatakan dalam satuan moneter dan (4) pelaporan yang memadai. Menurut penelitian Suwondo et.al (2013), instrument pengukuran kinerja terdiri atas aspek-aspek yang berpengaruh terhadap kualitas pelaksanaan tugas dan yang dapat diukur meliputi:(1) prestasi kerja; (2) keahlian; (3) prila$\mathrm{ku}$; (4) kepemimpinan.

\section{Kapasitas Aparatur Desa dan Kinerja Pengelolaan Desa}

Kapasitas dapat didefinisikan sebagai kemampuan manusia, lembaga dan masyarakat untuk melakukan keberhasilan, untuk mengidentifikasi dan mencapai tujuan mereka, dan untuk mengubah bila diperlukan untuk tujuan keberlanjutan, pengembangan dan kemajuan (Mouallem dan Analoui, 2014). Selanjutnya, menurut Soeprapto (2010), kapasitas adalah pemahaman, sikap, kemampuan, keterampilan, nilai-nilai, hubungan, perilaku, sumber daya, motivasi dan kondisi-kondisi yang memberikan kemungkinan bagi setiap sistem, jaringan kerja, organisasi, dan individu untuk menerapkan fungsi-fungsi mereka dan mencapai tujuan pembangunan yang telah ditetapkan antar waktu. Suryukoco (2010) mengungkapkan kapasitas atau kapabilitas adalah sebuah ukuran kemampuan dari seseorang atau institusi dalam menjalankan fungsinya. Dalam konteks pengelolaan keuangan, aparatur yang memiliki kapasitas berupa kompetensi akuntansi yang baik sehingga mampu memahami logika akuntansi yang menjadi dasar dalam pengelolaan keuangan yang profesional (Rafar et al., 2015)

Tjiptoherianto et al. (2010) menjelaskan kinerja dan kualitas kapasitas sumber daya manusia dalam melaksanakan suatu fungsi, termasuk akuntansi, dapat dilihat dari level of responsibility dan kompetensi sumber daya tersebut. Dalam kontek Gampong, perangkat Gampong memiliki tugas membantu Kepala Desa/Keuchik Gampong dalam mewujudkan tugas dan wewenangnya. Perangkat Gampong terdiri dari Sekretaris Gampong dan Perangkat Gampong lainnya. Salah satu perangkat Gampong adalah Sekretaris Gampong, yang diisi dari Pegawai negri sipil. Sekretaris Gampong diangkat oleh Sekretaris daerah Kabupaten/Kota atas nama Bupati/ Walikota. Perangkat Gampong lainnya diangkat oleh Keuchik dari penduduk Gampong, yang ditetapkan dengan keputusan Keusyik. Perangkat Gampong juga mempunyai tugas untuk mengayomi kepentingan masyarakat.

Qanun Kabupaten Bireuen No. 3 Tahun 2012 pasal 7 tentang Pemerintahan Gampong terdiri dari (1) Keuchik (2) Tuha Lapan, dan (3) Perangkat Gampong. Keuchik mempunyai wewenang selain pemegang kekuasaan pengelolaan keuangan Gampong juga memimpin penyeleng- 
garaan pemerintah Gampong berdasarkan kebijakan yang ditetapkan oleh Tuha Peut, menyusun dan mengajukan rancangan APBG (Anggaran Pendapatan Belanja Gampong) untuk dibahas dan mengkoordinasikan pembangunan Gampong secara partisipatif dan melaksanankan wewenang lain sesuai dengan peraturan perundang-undangan sedangkan perangkat Gampong yang lain seperti sekretaris dan KAUR (Kepala Urusan) Gampong bertugas membantu Keuchik dalam melaksanakan tugas penyelenggaraan pemerintah, administrasi, pembangunan, dan tata laksana serta memberikan pelayanan administratif.

Islami (2016) menyatakan kapasitas merupakan suatau kemampuan yang dimiliki oleh individu suatu organisasi atau suatu sistem dalam melaksanakan fungsi-fungsinya secara efektif, efisien, dan berkelanjutan sesuai dengan aturan yang berlaku untuk mencapai tujuan bersama dalam pembangunan. Pengukuran variabel ini dapat diukur dengan menggunakan indikator berikut: (1) Pemahaman, yaitu memahami dan melaksanakan tugas dan pokok fungsi, misalnya pemahaman dalam menghasilkan informasi bernilai dan dapat dipercaya (Riyanti et al., 2015). (2) Keterampilan, yaitu terampil dalam melaksanakan tugas dan pokok funsinya, (3) Kemampuan, yaitu mampu melaksanakan tugas dan pokok fungsinya. Berdasarkan paparan di atas, maka hipotesis yang dirumuskan adalah:

$\mathrm{H}_{1}$ : Kapasitas aparatur desa berpengaruh terhadap kinerja pengelolaan keuangan desa

\section{Ketaatan Pelaporan Keuangan dan Kinerja Pengelolaan Keuangan Desa}

Ketaatan adalah kesediaan untuk tunduk kepada hukum/perintah atau menerima pernyataan yang dikemukan oleh pimpinan sebagai hal yang benar (Mudhafir, 1996). Berdasarkan Permendagri No. 113 Tahun 2014 tentang Pengelolaan Keuangan Desa, disebutkan bahwa kepala desa wajib menyampaikan laporan realisasi pelaksanaan APBDesa yang dapat dipertanggungjawabkan kepada bupati/walikota melalui camat paling lambat satu bulan setelah akhir tahun anggaran. Dengan jumlah dana yang tidak sedikit ini tidak menutup kemungkinan adanya tindakan penyelewengan yang berkaitan dengan pengelolaan dana desa yang harus dipertanggungjawabkan secara akuntabilitas. Jadi semakin taat aparatur desa terhadap pelaporan keuangan maka semakin bagus pula kinerja pengelolaan keuangan suatu desa tersebut.
Menurut Ikatan Akuntan Indonesia (2009), laporan keuangan merupakan hasil akhir dari sebuah proses pelaporan keuangan. Laporan keuangan yang lengkap terdiri dari laporan posisi keuangan, laporan perubahan ekuitas, laporan laba rugi, laporan perubahan posisi keuangan, catatan dan laporan lain serta materi penjelasan yang merupakan bagian tidak terpisahkan dari laporan keuangan. Dengan ditetapkannya Undang-undang No. 6 Tahun 2014, tidak hanya mengubah peran desa menjadi unit kecil pemerintah desa, tetapi juga sebagai entitas pelaporan yang wajib melaporkan setiap kegiatan yang dilakukan. Laporan keuangan bertujuan untuk memberikan informasi, gambaran kinerja perusahaan selama satu periode kepada pengambil keputusan, dan sebagai gambaran bagaimana kondisi keuangan organisasi atau perusahaan tersebut.

SAP (Standar Akuntansi Pemerintahan) melalui PP. No. 24 Tahun 2005 yang merupakan SAP pertama yang di miliki oleh Pemerintah Indonesia. Kedudukan Standart Akuntansi Pemerintahan (SAP) adalah sebagai berikut: (1) SAP merupakan prinsip-prinsip akuntansi yang diterapkan dalam penyusunan dan penyajian laporan keuangan pemerintah, (2) SAP merupakan serangkaian prosedur manual maupun yang terkomputerisasi mulai dari pengumpulan data, pencatatan, pengikhtisaran dan pelaporan posisi keuangan, dan operasi keuangan pemerintah, (3) Pemerintah pusat maupun daerah menyusun sistem akuntansi pemerintahan yang mengacu pada SAP.

Dalam Permendagri No.113 Tahun 2014 mengatur mengenai asas pengelolaan keuangan desa yang meliputi transparansi, akuntanbel, partisipatif \& tertib, dan disiplin anggaran. Transparansi bermakna bahwa segala akses terhadap informasi dan proses pengambilan keputusan dimiliki oleh masyarakat dengan tujuan untuk memastikan pengelolaan kegiatan diketaui umum. Akuntanbel dalam hal konteks ini didefinisikan sebagai pertanggungjawaban secara moral, teknis, hukum, dan administratif. Pengelolaan keuangan pemerintah harus melibatkan masyarakat secara aktif sejak fase perencanaan sampai dengan pengawasan kegiatan (parsitipasif). Selanjutnya, tertib dan disiplin anggaran yang tercermin dari konsistensi, tepat waktu, tepat jumlah, dan taat asas. Berdasarkan paparan tersebut, maka hipotesis yang dirumuskan adalah:

$\mathrm{H}_{2}$ : Ketaatan pelaporan keuangan desa berpengaruh terhadap kinerja pengelolaan keuangan desa. 


\section{Kualitas Pengawasan BPD dan Kinerja Pengelolaan Keuangan Desa}

Kualitas adalah level yang menggambarkan serangkaian karakteristik yang melekat dan memenuhi ukuran tertentu (Dale, 2003). Assauri (2008) mengartikan kualitas diartikan sebagai komponen yang ada dalam suatu barang atau hasil yang menyebabkan barang tersebut dapat digunakan sesuai dengan tujuan yang dimaksud atau dibutuhkan. Dengan demikian pengawasan kualitas adalah suatu aktivitas untuk menjaga dan mengarahkan agar kualitas produk perusahaan dapat dipertahankan. Di sisi lain, pengawasan adalah proses di mana manajemen ingin mendapatkan informasi tentang apa yang bawahan kerjakan dan kesusuaiannya dengan perintah, rencana, perintah, tujuan, kebijakan yang telah disepakati (Maringan, 2004).

Sementara itu, kualitas pengawasan adalah menjaga dan mengendalikan kualitas aplikasi dengan pengawasan yang rutin sepajang siklus untuk mendapatkan hasil yang optimal. Kualitas pengawasan dilakukan denga cara mendorong atau memotivasi orang yang tepat untuk melakukan kegiatan yang tepat dengan informasi yang tepat pada saat yang tepat untuk mencapai hasil yang tepat (Balemans, 2013). Menurut Permedagri No. 113 Tahun 2014 menyatakan bahwa BPD adalah institusi yang bertanggungjawab menjalankan fungsi pemerintahan yang anggotanya merupakan representasi penduduk desa berdasarkan keterwakilan area yang ditetapkan secara demokratis. Dwipayana dan Eko (2003) juga menyatakan bahwa BPD merupakan aktor masyarakat politik yang paling nyata dan dekat di tingkat desa yang memainkan peran sebagai jembatan antara elemen masyarakat dan pemerintah desa. Apabila dikaitkan dengan struktur organisasi dalam lingkup kecil, Kepala desa sebagai (eksekutif) sedangkan BPD sebagai (legislatif).

BPD sebagai badan perwakilan merupakan wahana untuk melaksanakan demokrasi pancasila. Kedudukan BPD dalam struktur pemerintah desa adalah sejajar dan menjadi mitra dari Pemerintah Desa. Hal ini ditegaskan dalam Undang-Undang No. 32 Tahun 2004 tentang Pemerintah Daerah bahwa pemerintah desa adalah kegiatan pemerintah yang dilaksanakan pemerintah desa dan Badan Permusyawaratan Desa. Kualitas pengawasan dapat diukur dengan indikator-indikator sebagai berikut (Manullang, 2008:184): (1) Skedul pengawasan, (2) Standarisasi pengawasan, (3) Hubungan timbal balik (Feedback). Berdasarkan paparan tersebut, maka hipotesis yang dirumuskan adalah:

$\mathrm{H}_{3}$ : Kualitas pengawasan BPD berpengaruh terhadap kinerja pengelolaan keuangan desa

\section{METODE PENELITIAN}

Penelitian ini memiliki populasi yaitu seluruh Gampong yang berada dalam wilayah Kecamatan Gandapura yaitu 40 Gampong. Responden dalam penelitian ini meliputi Keuchik (kepala desa) Gampong, Bendahara, Tuha Peut (tokoh masyarakat yang menjadi anggota BPD) dan Pedamping Gampong (pendamping desa). Jadi jumlah narasumber dalam penelitian ini adalah 160 responden, maka dari itu penelitian ini menggunakan metode sensus/total sampling.

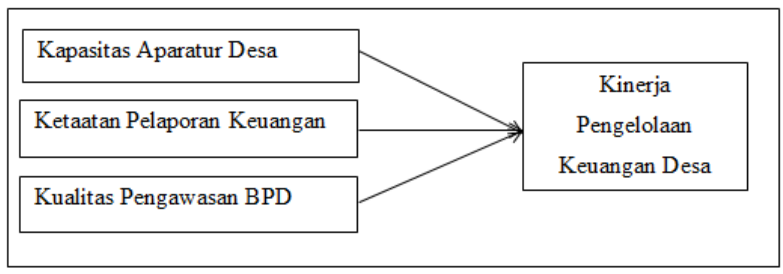

\section{Gambar 1. Model Penelitian}

Adapun teknik pengumpulan data yang dipilih yaitu dengan langsung menyerahkan kuesioner pada responden yang dituju dengan pertanyaan-pertanyaan terstruktur. Data yang diolah dalam penelitian ini adalah data primer yang merupakan data yang langsung diperoleh dari subjek penelitian. Pengumpulan data dilakukan dengan cara mengedarkan kuesioner yang berisi pernyataan yang berhubungan dengan variabel yang diteliti. Responden diminta untuk menentukan alternatif pilihan jawaban terhadap masingmasing pertanyaan-pernyataan terkait. Diharapkan melalui kuisioner, peneliti akan mendapatkan informasi dari subjek yang berkaitan langsung dengan masalah dan menjadi fokus utama dalam penelitian ini. Kuesioner yang digunakan dalam penelitian ini adalah kuesioner tertutup, dimana penyataan telah memiliki alternatif jawaban (option), yaitu berdasarkan skala likert. Skala likert digunakan untuk menghitung pendapat, persepsi, dan sikap seseorang atau sekelompok orang (Sugiyono, 2013).

Pada penelitian ini, variabel independen yang diteliti adalah kapasitas aparatur desa, ketaatan pelaporan keuangan, dan kualitas pengawasan BPD (Badan Permusyawaratan Desa). Variabel 
dependen pada penelitian ini adalah kinerja pengelolaan keuangan desa. Variabel kinerja perusahaan diukur berdasarkan indikator efisiensi, efektifitas, ekonomis, dan pelaporan yang memadai (Mardiasmo, 2009:4). Pada penelitian ini, analisis regresi linear berganda digunakan untuk mengolah data penelitian. Perumusan dari regresi linear berganda dari penelitian ini sebagai berikut:

$$
Y=a+\beta_{1} X_{1}+\beta_{2} X_{2}+\beta_{3} X_{3}+\varepsilon
$$

Keterangan:

$\mathbf{Y}=$ Kinerja pengelolaan keuangan desa

$\mathbf{X}_{\mathbf{1}}=$ Kapasitas aparatur desa

$\mathbf{X}_{\mathbf{2}}=$ Ketaatan pelaporan keuangan

$\mathbf{X}_{\mathbf{3}}=$ Kualitas pengawasan BPD

$\boldsymbol{\beta}_{1}, \boldsymbol{\beta}_{2}, \boldsymbol{\beta}_{3}=$ Koefisien $\mathrm{x}_{1}, \mathrm{x}_{2}, \mathrm{x}_{3}$

$\mathbf{a}=$ Konstanta

$\boldsymbol{\varepsilon}=$ error term

Penelitian ini merupakan penelitian sensus, sehingga tidak dilakukan pengujian signifikansi. Dalam pengujian hipotesis penelitian yang tidak menggunakan sampel, tidak ada istilah signi- fikansi, karena signifikansi artinya hipotesis yang telah terbukti pada sampel dapat diberlakukan ke populasi (Sugiyono,2008). Menurut Sekaran (2006) operasional variabel adalah setiap hal yang dapat membedakan atau menghasilkan perbedaan pada nilai. Penelitian ini menggunakan dua variabel, yaitu variabel independen dan variabel dependen. Variabel independen dalam penelitian ini ada tiga yaitu kapasitas aparatur desa, ketaatan pelaporan keuangan, dan kualitas pengawasan BPD, sedangkan variabel dependen adalah kinerja pengelolaan keuangan desa.

\section{HASIL DAN PEMBAHASAN}

Dari keseluruhan kuesioner yang didistribusikan, hanya terdapat 128 kuesioner yang kembali (nilai responden rate $=80 \%$ ) yang mewakili 32 Gampong: Sisanya tidak kembali atau tidak lengkap jawaban yang diberikan oleh responden. Untuk mengetahui bagaimana gambaran kondisi variabel dalam penelitian ini maka dilakukan analisis statistik deskriptif. Analisis statistik deskriptif adalah teknik deskriptif yang mampu mengubah

Tabel 1. Operasionalisasi variabel

\begin{tabular}{|c|c|c|c|c|}
\hline Variabel & Definisi operasional & Indikator & $\begin{array}{c}\text { Skala } \\
\text { pengukuran }\end{array}$ & $\begin{array}{c}\text { Sumber } \\
\text { instrumen }\end{array}$ \\
\hline $\begin{array}{l}\text { Kinerja } \\
\text { Pengelolaan } \\
\text { keuangan } \\
\text { desa (Y) }\end{array}$ & $\begin{array}{l}\text { Hasil kerja atau prestasi aparatur desa } \\
\text { dalam melaksanakan seluruh kegiatan } \\
\text { secara ekonomis, efisiensi, efektivitas dan } \\
\text { pelaporan yang memadai meliputi peren- } \\
\text { canaan, pelaksanaan, pelaporan dan } \\
\text { pertanggungjawaban keunagan desa. }\end{array}$ & $\begin{array}{ll}\text { - } & \text { Efisiensi } \\
\text { - } & \text { Efektivitas } \\
\text { - } & \text { Ekonomis } \\
\text { - } & \text { Pelaporan yang } \\
& \text { memadai }\end{array}$ & Interval & $\begin{array}{l}\text { Mardiasmo } \\
(2009)\end{array}$ \\
\hline $\begin{array}{l}\text { Kapasitas } \\
\text { aparatur desa } \\
\text { (X1) }\end{array}$ & $\begin{array}{l}\text { Kemampuan individu yang harus dimiliki } \\
\text { oleh aparatur desa meliputi pemahaman, } \\
\text { keterampilan dan kemampuan untuk } \\
\text { melaksanakan tugas pokok dan fungsinya } \\
\text { secara efektif, efisien, dan berkelanjutan }\end{array}$ & $\begin{array}{ll}\text { - } & \text { Pemahaman } \\
\text { - Keterampilan } \\
\text { - Kemampuan }\end{array}$ & Interval & Islami (2016) \\
\hline $\begin{array}{l}\text { Ketaatan } \\
\text { Pelaporan } \\
\text { Keuangan } \\
\text { Desa (X2) }\end{array}$ & $\begin{array}{l}\text { Kesediaan untuk tunduk kepada hukum/ } \\
\text { aturan yang berlaku dalam melaksanakan } \\
\text { tugas dan fungsinya aparatur desa untuk } \\
\text { mempertanggungjawabkan laporan keua- } \\
\text { ngan secara transparansi, akutabel, parti- } \\
\text { sipasif dan tertib administrasi dan pera- } \\
\text { turan. }\end{array}$ & $\begin{array}{l}\text { - } \text { Transparansi } \\
\text { - Akuntabel } \\
\text { - } \text { Partisipatif } \\
\text { - } \text { Tertib } \\
\text { administrasi dan } \\
\text { peraturan }\end{array}$ & Interval & $\begin{array}{c}\text { Permendagri } \\
\text { No.113 tahum } \\
\text { 2014) }\end{array}$ \\
\hline $\begin{array}{l}\text { Kualitas } \\
\text { Pengawasan } \\
\text { BPD (X3) }\end{array}$ & $\begin{array}{l}\text { Kegiatan yang dilakukan oleh BPD untuk } \\
\text { mengetahui hasil pelaksanan pekerjaan } \\
\text { yang dilakukan aparatur desa apakah } \\
\text { sudah sesuai dengan perencanaan dan } \\
\text { sesuai dengan peraturan yang berlaku. }\end{array}$ & $\begin{array}{ll}\text { - } & \text { Skedul } \\
\text { - } & \text { Stangawasan } \\
\text { - } & \text { Hubisasi } \\
\text { timbal balik } \\
\text { (feedback) }\end{array}$ & Interval & $\begin{array}{l}\text { Manullang } \\
(2008: 184)\end{array}$ \\
\hline
\end{tabular}


Tabel 2. Statistik Deskriptif Variabel Penelitian

\begin{tabular}{lccccc}
\hline \multicolumn{1}{c}{ Variabel } & N & Nilai terendah & Nilai tertinggi & Rata-rata & Std. Deviation \\
\hline Kinerja & 32 & 4,12 & 5,20 & 4,5763 & 0,27270 \\
Kapasitas & 32 & 4,12 & 4,87 & 4,4456 & 0,17553 \\
Ketaatan & 32 & 3,78 & 4,96 & 4,6162 & 0,27725 \\
Kualitas & 32 & 3,90 & 4,90 & 4,5813 & 0,25453 \\
Valid N & 32 & & & & \\
\hline
\end{tabular}

sebuah gambaran suatu data menjadi sebuah informasi yang lebih menarik, jelas dan tidak sulit untuk dipahami (Wolk et al., 2015). Hasil statistik deskriptif dapat dilihat pada Tabel 2.

Berdasarkan tabel 2 diatas dapat diambil definisi bahwa variabel kinerja pengelolaan keuangan memiliki nilai rata-rata sebesar 4,5763. Hal ini menggambarkan bahwa sebagian besar responden cenderung menjawab dengan sangat setuju untuk pertanyaan yang diajukan berkaitan dengan masalah kinerja pengeolaan keuangan desa. Nilai minimum variabel kinerja pengelolaan keuangan desa adalah sebesar 4,12 yang artinya adalah ada responden yang memberikan jawaban tidak pasti untuk pertanyaan yang diajukan, sedangkan nilai tertinggi variabel kinerja pengelolaan keuangan desa adalah sebesar 5,20 yang artinya adalah ada responden yang cenderung menjawab sangat setuju untuk pertanyaan yang diajukan berkaitan dengan kinerja pengelolaan keuangan desa.

Variabel kapasitas aparatur desa memiliki nilai rata-rata sebesar 4,4456. Ini dapat diartikan bahwa sebagian responden cenderung memberikan jawaban setuju untuk pernyataan yang diajukan yang berkaitan dengan masalah kapasitas aparatur desa. Nilai terendah untuk variabel kapasitas aparatur desa adalah sebesar 4,12 yang artinya ditemukan responden yang menjawab tidak pasti untuk pertanyaan yang diajukan, sedangkan nilai maksimum variabel kapasitas aparatur desa adalah sebesar 4,87 yang artinya adalah terdapat responden cenderung menjawab setuju untuk pertanyaan yang ditanyakan berkaitan dengan kapasitas aparatur desa.

Nilai rata-rata untuk variabel ketaatan pelaporan keuangan sebesar 4,6162. Ini menunjukkan bahwa sebagian besar responden lebih banyak menjawab sangat setuju untuk pertanyaaan yang diajukan mengenai masalah ketaatan pelaporan keuangan. Nilai minimum variabel ketaatan pelaporan keuangan adalah sebesar 3,78 yang berarti bahwa terdapat responden yang menjawab tidak pasti untuk pertanyaan yang diajukan, sedangkan nilai maksimum variabel ketaatan pelaporan keuangan adalah sebesar 4,96 yang artinya terdapat responden cenderung menjawab sangat setuju untuk pertanyaan yang dianjukan berkaitan dengan ketaatan pelaporan keuangan.

Variabel kualitas pengawasan BPD memiliki nilai rata-rata sebesar 4,5813. Ini menujukkan bahwa sebagian besar responden cenderung menjawab sangat setuju untuk pertanyaaan yang berkaitan dengan masalah kualitas pengawasan BPD. Nilai minimum variabel kualitas pengawasan BPD adalah sebesar 3,90 yang artinya terdapat responden yang cenderung menjawab tidak pasti untuk pertanyaan yag diajukan, sedangkan nilai maksimum variabel kualitas pengawasan BPD adalah sebesar 4,90 yang artinya adalah terdapat responden yang cenderung menjawab sangat setuju untuk variabel kualitas pengawasan BPD.

\section{Hasil Pengujian Kualitas Instrumen}

\section{Uji Validitas}

Berdasarkan hasil uji validitas ditemukan bahwa terdapat satu pertanyaan yaitu KPKD6 yang tidak valid karena nilai $r$ hitung lebih kecil dari pada nilai $r$ tabel yaitu $0,451<0,482$. Dengan demikian pernyataan tersebut dihapus dari item pertanyaan yang disajikan pada kuesioner penelitian atau tidak digunakan pada instrumen untuk penelitian karena tidak valid. Sedangkan pertanyaan lainnya memiliki nilai $r$ hitung lebih besar dari pada nilai $r$ tabel, sehingga dapat disimpulkan layak dan dapat digunakan pada instrumen penelitian, serta memiliki validitas konstrak atau terdapat konsistensi internal yang berarti bahwa data yang diperoleh adalah valid dan dapat digunakan untuk penelitian.

\section{Uji Reabilitas}

Uji reabilitas menghasilkan nilai kritis Cronbach Alpha untuk semua pertanyaan di atas 0,60 yaitu kapasitas aparatur desa sebesar 0,874\%, ketaatan pelaporan keuangan sebesar 0,928\%, kualitas pengawasan BPD sebesar 0,910\% dan kinerja pengelolaan keuangan desa sebesar 0,874\%. Hal ini menunjukkan bahwa instrumen tersebut memiliki reliabilitas yang sangat baik. 


\section{Hasil Pengujian Hipotesis}

\section{Model Persamaan Regresi Linear Berganda}

Untuk mendapatkan bukti empiris mengenai pengaruh variabel-variabel independen terhadap variabel dependen maka menggunakan analisis regresi linear berganda dengan menggunakan perangkat program SPSS 20. Variabel independen dalam penelitian ini adalah kapasitas aparatur desa (X1), ketaatan pelaporan keuangan (X2), dan kualitas pengawasan BPD (Badan Permusyawaratan Desa). Sedangkan variabel dependennya adalah kinerja pengelolaan keuangan desa (Y). Hasil pengujian regresi linear berganda dapat dilhat pada Tabel 3.

Koefisien determinasi $\left(\mathbf{R}^{2}\right)$ sebesar 0,555 memiliki arti bahwa kinerja pengelolaan keuangan desa dapat dijelaskan oleh kapasitas aparatur desa, ketaatan pelaporan keuangan, dan kualitas pengawasan BPD sebesar 55,5\% selebihnya sebesar $44,5 \%$ dijelaskan oleh variabel-variabel lain yang tidak termasuk dalam penelitian ini. Dengan adanya kapasitas aparatur desa, ketaatan pelaporan keuangan dan kualitas pengawasan BPD dapat memberikan suatu perubahan yang baik dalam meningkatkan kinerja pengelolaan keuangan desa pada Kecamatan Gandapura Kabupaten Bireuen. Hal ini menunjukkan bahwa semakin baik kapasitas aparatur desa, ketaatan pelaporan keuangan dan kualitas pengawasan BPD maka akan meningkatkan kinerja pengelolaan keuangan desa pada Kecamatan Gandapura di Kabupaten Bireuen.

\section{Pengaruh Kapasitas Aparatur Desa terhadap Kinerja Pengelolaan Keuangan Desa}

Hasil pengujian hipotesis pertama menunjukkan bahwa nilai koefisien $\beta_{1}$ sebesar 0,134. Nilai koeefisien positif ini menandakan bawah bahwa kapasitas aparatur desa berpengaruh positif terhadap kinerja pengelolaan keuangan desa. Hasil pengujian ini mendukung hipotesis alternatif pertama. Hal ini menunjukkan bawa semakin tinggi tingkat kapasitas aparatur desa tentang pengelolaan keuangan desa maka akan semakin meningkatkan kinerja pengelolaan keuangan desa. Hasil penelitian ini konsisten dengan hasil penelitian yang dilakukan oleh Aristia (2015) yang menghasilkan kesimpulan bahwa kemampuan aparatur desa dalam hal kapasitas sumber daya manusia yaitu pengetahuan sangat menentukan baik buruknya kinerja pengelolaan desa tersebut. Hal ini sejalan dengan pendapat Asrori (2014) yang mengatakan bahwa pencapaian kinerja dipengaruhi oleh kapasitas aparatur desa yang memadai termasuk kemampuan, pengetahuan, pengalaman dan motivasi lingkungan kerja.

Hasil penelitian ini dapat dijadikan alasan untuk merekrut aparatur desa yang memiliki kualifikasi pendidikan yang lebih tinggi. Berdasarkan hasil penelitian ini, aparatur desa pada Kecamatan Gandapura di Kabupaten Bireuen yang mayoritas berpendidikan SMA. Dari 128 responden yang terdiri dari 32 Gampong, hanya 45 orang $(35,1 \%)$ aparatur Gampong yang berpendidikan akhir S1, sedangkan selebihnya 83 orang $(64,8 \%)$ aparatur Gampong yang berpendidikan akhir SMA. Meskipun aparatur Gampong banyak yang mempunyai latar belakang pendidikan SMA namun sebagian besar mereka telah memahami pengelolaan keuangan dengan baik. Variabel kapasitas aparatur desa mempunyai pengaruh paling kecil yaitu sebesar $13,4 \%$ dibandingkan dengan variabel lainnya, hal ini tidak menjadi kendala dalam meningkatkan kinerja pengelolaan keuangan desa. Pengaruh yang relatif kecil ini dapat dikaitkan dengan mudah dipahaminya prosedur akuntansi dan pelaporan keuangan. Alasan lain adalah pelaporan akuntansi sudah dilakukan dengan menggunakan software dan para aparatur desa sudah diberikan pelatihan yang cukup untuk menjalankan sistem tersebut.

\section{Pengaruh Ketaatan Pelaporan Keuangan terhadap Kinerja pengelolaan Keuangan Desa}

Berdasarkan pengujian hipotesis kedua menunjukkan hasil bahwa ketaatan pelaporan keuangan berpengaruh terhadap kinerja pengelolaan keuangan desa, dimana nilai koefisien regresi $\beta_{2}$ sebesar 0,174. Hasil penelitian ini mendukung hipotesis alternatif yang kedua. Hasil tersebut dapat diintepretasikan bahwa ketaatan pelaporan keuangan desa dapat meningkatkan kinerja pengelolaan keuangan desa. Dengan kalimat lain, semakin taat aparatur desa dalam melaporkan keuangannya maka semakin tinggi pula pengaruhnya terhadap kinerja pengelolaan keuangan desa. Hasil penelitian ini sejalan dengan penelitian yang dilakukan oleh Adi (2013) yang menunjukkan bahwa implementasi pengelolaan dan penatausahaan keuangan desa berpengaruh terhadap kelancaran administrasi pemerintah desa. Hal ini disebabkan oleh semakin taat aparatur desa da- 
Tabel 3. Hasil Pengujian Regresi Linear Berganda

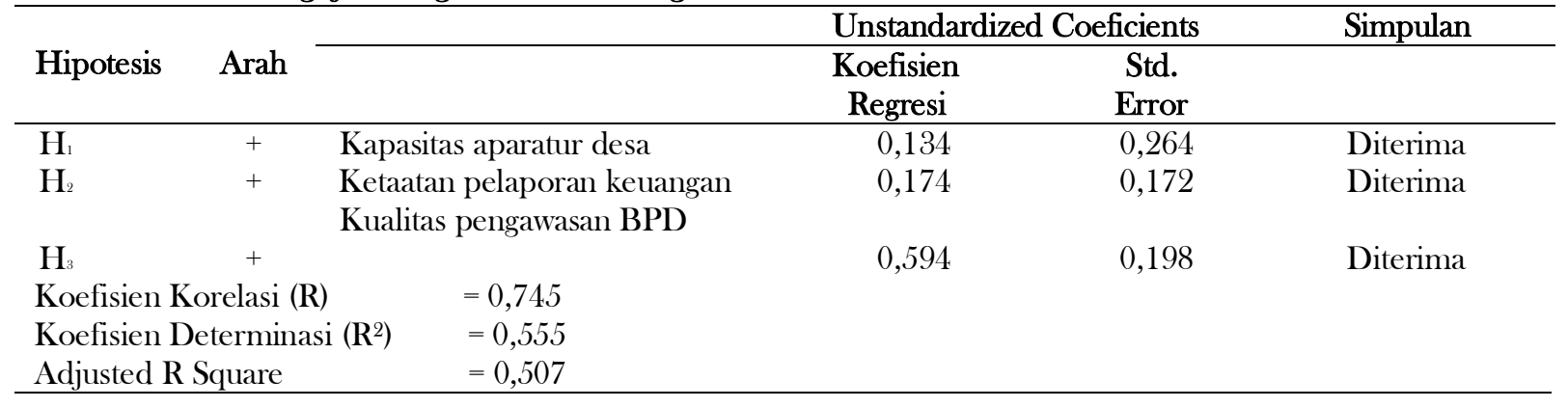

lam membuat pelaporan keuangan desa maka semakin baik pula kinerja pengelolaan keuagan desa. Dengan diberikannya wewenang tersebut pemerintah desa memiliki tanggung jawab untuk melaporkan pertanggung jawab kepada pemerintah Kabupaten. Ketaatan pelaporan keuangan pada Kecamatan Gandapura di Kabupaten Bireuen hanya mampu mempengaruhi kinerja pengelolaan keuangan desa sebesar 17,4\%.

\section{Pengaruh Kualitas Pengawasan BPD terhadap Kinerja Pengelolaan Keuangan Desa}

Berdasarkan hasil pengujian hipotesis ketiga didapatkan hasil bahwa kualitas pengawasan BPD memiliki pengaruh positif terhadap kinerja pengelolaan keuangan desa (nilai koefisien regresi $\beta_{3}$ sebesar 0,594). Nilai koefisien regresi sebesar 0,594 dapat diartikan bahwa kualitas pengawasan BPD berpengaruh positif terhadap kinerja pengelolaan keuangan desa. Kualitas pengawasan BPD pada Kecamatan Gandapura Kabupaten Bireuen mampu mempengaruhi kinerja pengelolaan keuangan desa sebesar 59,4\%. Nilai koefisien ini tertinggi dibandingkan variabel lainnya. Hal ini dapat diartikan bahwa kinerja pengelolaan keuangan desa umumnya ditentukan oleh bagaimana kualitas pengawasan yang dilakukan oleh BPD. Hasil penelitian ini sejalan dengan temuan Adha (2016) yang menemukan pengawasan BPD berpengaruh positif terhadap kinerja kepala desa dalam pembangunan.

\section{SIMPULAN}

Dari hasil pengujian hipotesis dan pembahasan yang telah diuraikan sebelumnya, dapat diambil kesimpulan bahwa kapasitas aparatur desa, ketaatan pelaporan keuangan, dan kualitas pengawasan $\mathrm{BPB}$ memiliki pengaruh positif terhadap kinerja pengelolaan keuangan desa pada Kecamatan Gandapura di Kabupaten Bireuen.
Dengan demikian, penelitian ini sejalan dengan hasil penelitian sebelumnya. Penelitian ini memiliki beberapa keterbatasan yaitu skope penelitian yang relatif kecil (satu kecamatan), tidak digunakannya metode wawancara sehingga hasil penelitian tidak dapat dikonfirmasi dan dijelaskan lebih detail serta variabel penelitian yang relatif sedikit. Dengan demikian, kami menyarankan penelitian lebih lanjut ke depan yang menambahkan metode wawancara dalam pengambilan data penelitian, menambahkan variabel lain misalnya pemanfaatan teknologi informasi dan komitmen aparatur desa serta jumlah desa yang lebih banyak dan mewakili beberapa kecamatan sehingga daya generalisasinya lebih tinggi.

\section{DAFTAR PUSTAKA}

Adha, A. H.. 2016. Pengaruh Pengawasan Badan Permusyawaratan Desa (BPD) Terhadap Kinerja Kepala Desa Dalam Pembangunan Desa Rambah Utama Kecamatan Rambah Samo Kabupaten Rokan Hulu. Jurnal Online Mahasiswa, 3 (2), 36-47.

Amirullah, M. A., I. Ulum, dan A. Prasetyo. 2016. Analysis of Financial Management Based on Minister Home Affairs Regulation 113 of 2014 (Case study in Brumbungan Kidul Village, Maron Sub-district, Probolinggo Regency). Proceedings of Internastional Conference on Accounting and Finance, Universitas Muhammadiyah Yogyakarta, Maret 2016.

Antlöv, H., A. Wetterberg dan L. Dharmawan. 2016. Village Governance, Community Life, and the 2014 Village Law in Indonesia, Bulletin of Indonesian Economic Studies, 52 (2), 161-183.

Aristia, R. 2015. Studi Tentang Kemampuan Aparatur Desa dalam Pelayanan Admi- 
nistrasi Kependudukan di kampung Dtah Bilang Baru Kecamatan Long Hubung Kabupaten Mahakam Ulu. Jurnal IImu Pemerintah, 3 (1), 443-457.

Asrori. 2014. Kapasitas Aparatur Desa Dalam Penyelenggaraan Pemerintah Desa di Kabupaten Kudus. Jurnal Bina Praja, 6 (2), 73 88.

Assauri, S. 2008. Manajemen Produksi dan Operasi. Edisi Revisi. Jakarta: Fakultas Ekonomi Universitas Indonesia.

Balemans, A. R. M. 2013. Quality Supervision. Sogeti: Worldwide.

Dale, M. 2003. Developing Management Skill (Terjemahan). Jakarta: PT. Gramedia.

Dwipayana, A. dan S. Eko. 2003. Membangun Good Governance di Desa. Yogyakarta: Ires Press.

Ikatan Akuntansi Indonesia Indonesia. 2009. Standar Akuntansi Keuangan. PSAK No. 1: Penyajian Laporan Keuangan. Jakarta: Salemba Empat.

Jaitun. 2013. Kinerja Aparatur Desa Dalam Penyelenggaraan Pemerintah Desa di Desa Sepala Dalung Kecamatan Sesayap Hilir Kabupaten Tana Tidung. Jurnal Pemerintah Integratif, 1 (1), 13-27.

Jumingan. 2006. Analisa Laporan Keuangan. Jakarta: Bumi Aksara.

Lestari, A. K. D., A. T. Atmadja, dan I. M. P. Adiputra. 2014. Membedah Akuntabilitas Praktik Pengelolaan Keuangan Desa Pakraman Kubutambahan, Kecamatan Kubutambahan, Kabupaten Buleleng, Provinsi Bali (Sebuah Studi Interpretif pada Organisasi Publik Non Pemerintahan). JIMAT (Jurnal Ilmiah Mahasiswa Akuntansi S1), 2 (1), 115-131.

Mangkunegara, A. A. A. P.. 2007. Manajemen Sumber Daya Manusia. Bandung: PT. Remaja Rosdakarya.

Manullang. 2008. Dasar-dasar Manajemen. Yogyakarta: Gadjah Mada University Press.

Mardiasmo. 2009, Akuntansi Sektor Publik, Yogyakarta: Penerbit ANDI.

Maringan, M. S. 2004. Dasar-Dasar Administrasi dan Manajemen. Jakarta: Ghalia Indonesia.

Moeheriono. 2012. Perencanaan, Aplikasi \& Pengembangan Indikator Kinerja Utama Bisnis dan Publik. Jakarta: Rajawali Pers.

Mouallem, Lara El, \& Farhad Analoui. 2014. The Need for Capacity Building in Human Resource Management Related Issues: A Case Study from the Middle East
(Lebanon). European Scientific Journal, 14, 245-254.

Nurzianti, R. dan Anita. 2014. Pengaruh karakteristik tujuan anggaran terhadap kinerja aparat pemerintah daerah di kabupaten Aceh Besar. Jurnal Dinamika Akuntansi dan Bisnis, 1 (1), 58-71

Peraturan Menteri Dalam Negeri Republik Indonesia Nomor 113 Tahun 2014 tentang Pengelolaan Keuangan Desa.

Peraturan Menteri Dalam Negeri Republik Indonesia Nomor 37 Tahun 2007 tentang Pengelolaan Keuangan Daerah.

Peraturan Pemerintah Nomor 24 Tahun 2005 tentang Standar Akuntansi Pemerintah.

Peraturan Pemerintah Nomor 43 Tahun 2014 tentang Peraturan Pelaksanaan UU Nomor 6 Tahun 2014 tentang desa.

Peraturan Bupati Kabupaten Bireuen Nomor 9 Tahun 2015 tentang Alokasi Dana Gampong.

Qanun Kabupaten Bireuen No. 3 Tahun 2012 tentang Pemerintahan Gampong

Rafar, T. M., H. Fahlevi dan H. Basri. 2015. Pengaruh kompetensi pengelola keuangan dan akuntabilitas terhadap kinerja pengelolaan keuangan daerah. Jurnal Administrasi Akuntansi, 4 (2), 125-135.

Riyanti, Y., Nadirsyah dan H. Fahlevi. 2015. Pengaruh pemahaman akuntansi, pemanfaatan teknologi informasi dan peran internal audit terhadap efektivitas penyusunan laporan keuangan pada satuan kerja mahkamah syar'iyah di Aceh. Jurnal Administrasi Akuntansi, 4 (2), 80-90.

Sekaran, U. 2006. Research Methode for Business: Metodologi Peneltian untuk Bisnis. Buku 1. Edisi Empat. Jakarta: PT. Bumi Aksara.

Soeprapto, H. R. R. 2003. Pengembangan Kapasitas Pemerintah Daerah Menuju Good Governance. Pidato Pengukuhan Guru Besar dalam Ilmu Administrasi Pembangunan pada Fakultas Ilmu Administrasi Universitas Brawijaya.

Sofyani, H. 2017. Strategi Jitu Mencapai Sukses Dalam Pelaksanaan Tata Kelola Rencana Strategis, Keuangan, Akuntabilitas Dan Transparansi Dana Desa. Laporan Penelitian Hibah LP3M UMY.

Subroto, A. (2009). Accountability of Village Fund Allocation Management (case study in Tlogomulyo Sub-District, Temanggung 
Regency). Master Theses, Universitas Diponegoro.

Sugiyono. 2008. Metode Penelitian Kunatitatif Kualitatif dan R\&D. Bandung: Alfabeta.

Sugiyono. 2013. Metode Penelitian Pendidikan Pendidikan Pendekatan Kuantitatif, Kualitatif, dan $R \& D$. Bandung: ALFABETA.

Suryukoco. 2010. Peningkatan Kapasitas Pemerintah Desa. Melalui https://suryokocolink.wordpress.com.

Suwondo, L., M. Paramitha, dan D. Tjahjanulin. 2013. Kinerja Aparat Pemerintah Desa Dalam Rangka Otonomi Desa (Studi di Desa Gulun, Kecamatan Maospati, Kabupaten Magetan. Jurnal Administrasi Publik, 1 (4), 91-100.

Undang-Undang No. 32 Tahun 2004 tentang Pemerintah Daerah

Undang-Undang No. 6 Tahun 2014 tentang Desa.

Wibowo. 2011. Manajemen Perubahan. Jakarta: PT. Raja Grafindo Persada.

Yuliyanti, L. 2014. Pengaruh kinerja perusahaan terhadap harga saham perusahaan automotif dan component di bursa efek Jakarta. Jurnal Dinamika Akuntansi dan Bisnis, 1 (1), 1-11. 